the wool, although the sheep were provided with a constant diet and maintained indoors. New methods have been applied to the fractionation of the soluble fractions and those precipitated iso-electrically from oxidized wool, and an apparatus was designed for following detergent action under the microscope, and another constructed for studying the visco-elastic properties of wool fibres over five decades below 1 cycle per second, under controlled conditions of temperature and humidity. Working at very high dilution to minimize association, infra-red spectroscopy has shown that both phenol and pyrrole react with the CO group of the secondary amide N-n-butylacetamide in carbon tetrachloride as solvent, and combination of neither compound with the amide modifies the infra-red absorption band of the amide NH group.

In his chairman's address at the annual general meeting, Mr. John Foster Beaver, reviewing changes in the circumstances and outlook of the Research Association, after a reference to its pioneering work on the control of relative humidity and on the funda- mental properties and modes of operation of materials and processes used in the industry, said that the problem to-day was rather the significance for individual processing of the new knowledge being obtained from many other sources also. The Research Association had accordingly departed considerably from concentration on long-term research and was paying more attention to the immediate needs of the industry. During the past year more than 1,500 reports on consulting work were sent to members, and apart from solving an immediate difficulty, such reports indicate more general lines of research. For example, consulting work on stripey and barry pieces had led to an extensive programme on the effect of winding, warping and weaving tensions on the appearance of fabrics, which had indicated the degree of control required in these processes. During the year a series of six industrial lectures were given at Torridon on Saturday mornings as a new means of liaison with industry, and the attendance at these lectures had been extremely good.

\title{
THE PRODUCTION ENGINEERING RESEARCH ASSOCIATION
}

$\mathrm{T}$ HE new building of the Production Engineering Research Association of Great Britain was formally opened by the Right Hon. Lord Chandos, at the Melton Mowbray, Leicestershire, headquarters of the Association on July 3.

These new premises-which have cost $£ 250,000$, of which $£ 100,000$ has been contributed by the Department of Scientific and Industrial Research--comprise extensive workshops and laboratories for the investigation and development of production engineering techniques. They house machine-tools, recording and testing instruments and auxiliary equipment worth some $£ 500,000$.

The acquisition of these facilities constitutes a major stage in the development of the Association, which had been working in temporary accommodation -converted stables-since it was founded in 1946. The Association was sponsored in its initial stages by the Institution of Production Engineers, the Gauge and Tool Makers' Association, the Machine Tool Trades Association, the National Federation of Engineers' Tool Manufacturers and the Department of Scientific and Industrial Research, and had its origin in the Institution of Production Engineers' Research Department which was established at Loughborough College in 1939 under the direction of Dr. G. Schlesinger, formerly of the Technical University of Berlin. Dr. Schlesinger was succeeded by his deputy, Dr. D. F. Galloway, who has been director of research at the Production Engineering Research Association since its foundation.

The Production Engineering Research Association is a non-profit making institution, deriving its income of about $£ 250,000$ a year partly from the subscriptions of 640 industrial companies and partly from the Department of Scientific and Industrial Research. It has a staff of about 250 , and was established to assist member firms with their particular production engineering problems, undertaking practical investigations in the workshop or laboratory where necessary. Information services and technical training facilities are also provided. Visits are made regularly to each member firm by liaison engineers, members' staff are encouraged to visit the Association's workshops and laboratories, and there is a mobile unit equipped with cinema-cum-lecture theatre, and demonstration bay. A form of associate membership has recently been introduced for technical colleges and universities in Britain and the Commonwealth.

The primary objective of the Association is "to secure economic savings by the prompt and effective application of improved production techniques in members' workshops". One company has been shown how to save about $£ 40,000$ a year in the production of a single component; another is saving $£ 30,000$ a year by the cold extrusion of electrical components which had previously been produced by machining. Facilities are available for determining the causes of failure of components, for the selection and heattreatment of materials, for testing lubricants, and for hardness and precision measurement.

But although mainly concerned with the solving of specific problems of member firms, much of the Association's work-particularly on metal-forming and metal-cutting techniques, for which it is very well equipped - is of general interest and application. From the point of view of those engaged in fundamental production engineering research in the universities, one can but regret that the private and confidential consulting nature of the Association's special investigations and development projects prevents the publication of findings which would undoubtedly be of considerable interest and value. Although it is recognized that the Production Engineering Research Association has an obligation to undertake investigations which bring immediate material benefits to the companies that finance its activities, it is to be hoped that as the Association further develops, and particularly in so far as it is a Government-sponsored research unit, the members of its team will be given freedom to initiate, pursue and publicize more work of a more fundamental character.
N. A. DUDLEY 